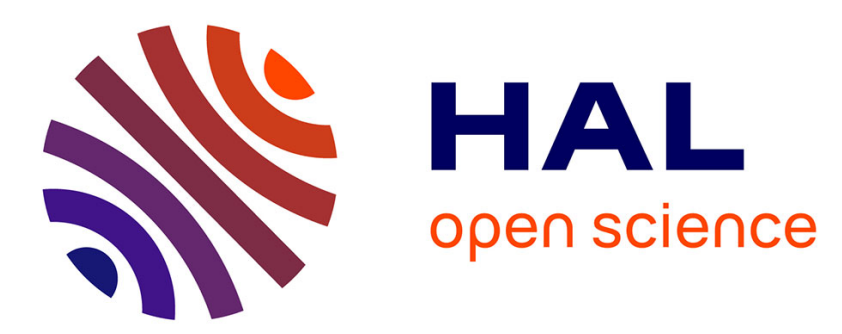

\title{
Comparison of methods to identify crop productivity constraints in developing countries. A review
}

Richard Kraaijvanger, Marthijn Sonneveld, Conny Almekinders, Tom

\author{
Veldkamp
}

\section{To cite this version:}

Richard Kraaijvanger, Marthijn Sonneveld, Conny Almekinders, Tom Veldkamp. Comparison of methods to identify crop productivity constraints in developing countries. A review. Agronomy for Sustainable Development, 2015, 35 (2), pp.625-637. 10.1007/s13593-014-0254-1 . hal-01284277

\section{HAL Id: hal-01284277 \\ https://hal.science/hal-01284277}

Submitted on 7 Mar 2016

HAL is a multi-disciplinary open access archive for the deposit and dissemination of scientific research documents, whether they are published or not. The documents may come from teaching and research institutions in France or abroad, or from public or private research centers.
L'archive ouverte pluridisciplinaire HAL, est destinée au dépôt et à la diffusion de documents scientifiques de niveau recherche, publiés ou non, émanant des établissements d'enseignement et de recherche français ou étrangers, des laboratoires publics ou privés. 


\title{
Comparison of methods to identify crop productivity constraints in developing countries. A review
}

\author{
Richard Kraaijvanger • Marthijn Sonneveld • \\ Conny Almekinders • Tom Veldkamp
}

Accepted: 9 September 2014 / Published online: 25 September 2014

(C) INRA and Springer-Verlag France 2014

\begin{abstract}
Selecting a method for identifying actual crop productivity constraints is an important step for triggering innovation processes. Applied methods can be diverse and although such methods have consequences for the design of intervention strategies, documented comparisons between various methods are scarce. Different variables can be used to characterize these methods. To typify them, we used two of these variables in a heuristic model: control over the research process and represented opinion. Here, we review 16 published papers that present outcomes of different methods to identify productivity constraints. The major findings are the following: (1) Variation in methods is wide. (2) Applying the heuristic model results in three main clusters of methods: farmer-control/farmer-opinion, scientist-control/scientist-opinion, and scientist-control/farmeropinion. (3) These clusters are scale level dependent. As a follow up, we compared in a case study the three different methods, representative for the three main clusters of the heuristic model, in order to assess their congruency. These methods
\end{abstract}

This article is dedicated to the memory of our friend and colleague Marthijn Sonneveld.

\footnotetext{
R. Kraaijvanger $\cdot$ M. Sonneveld

Soil Geography and Landscape Group, Wageningen University,

PO Box 47, 6700 AA Wageningen, The Netherlands

R. Kraaijvanger $(\bowtie)$

College of Dryland Agriculture, Mekelle University, PO Box 231, Mekelle, Ethiopia

e-mail: richard.kraaijvanger@wur.nl

C. Almekinders

Knowledge Technology and Innovation Group, Wageningen

University, PO Box 8130, 6700 EW Wageningen, The Netherlands

T. Veldkamp

Faculty of Geo-Information Science and Earth Observation (ITC),

Twente University, PO Box 217, 7500 AE Enschede,

The Netherlands
}

(focus group discussion, individual surveys, and contextual data collection) were applied in four localities in Tigray, Northern Ethiopia. We found that congruency between the methods, as indicated by Spearman- $\rho$ correlations, was not significant. In addition, we found that outcomes of individual surveys and contextual data collection among the different locations were correlated $(\mathrm{R}>0.70)$. No such correlation was found using focus group discussion. Both findings indicate that for a specific location different methods yielded different constraints and that variability between the locations is not reflected by using individual surveys and contextual data collection. Combined the review and case study demonstrate that process control and represented opinion have a manifest impact on generated outcomes. Because outcomes of productivity constraints assessments are methodology dependent, researchers are recommended to justify a priori their choice of method using the presented heuristic model.

Keywords Smallholder farming systems · Constraint identification $\cdot$ Focus group discussion · Tigray

Table of Contents

1. Introduction

2. Heuristic model and prototype methods

3. Different use of methodologies: a review

3.1. Presenting outcomes

3.2. Summarizing: using the heuristic model

4. Comparing different methods for the identification of productivity constraints in Tigray

4.1. Background and context

4.2. Study area description

4.3. The three prototype methods

4.4. Assessment of congruency 
4.5. Outcomes of applied methods

4.6. Comparability of outcomes

5. Discussion

5.1. Review of selected papers

5.2. Comparison of different methodologies within the same case study

5.3. Epistemological foundations

5.4. From identification of constraints to forwarding opportunities

6. Conclusion

7. References

\section{Introduction}

In rural, subsistence-based farming communities, crop productivity plays an essential role in livelihood development. In order to achieve sustainable food secure livelihoods, usually increasing crop productivity is considered an essential first step (Tittonell and Giller 2013). In many cases, this justifies the promotion of higher input technologies, for example in the form of Green Revolution style packages of new varieties, fertilizer application, and pest and weed control measures (Denning et al. 2009; Dethier and Effenberger 2012).

Despite the numerous past and present attempts, the adoption rate and impact of such improved technologies have generally been limited in the marginal areas (Chambers and Jiggins 1987; Longhurst and M. Lipton 1989; Kolavalli and Kerr 2002). The reasons for these failures are not always clear but might be partly related to a limited understanding of the real world constraints that farmers face in their attempts to maintain and improve their livelihoods.

These constraints are numerous and related to both biophysical and socioeconomic factors. Biophysical factors constraining crop productivity for farmers include, for example the incidence of droughts, the incidence of soil erosion, and a low inherent nutrient status of their soils (Veldkamp et al. 2001; Nyssen et al. 2004; Hengsdijk et al. 2005). Socioeconomic factors can be endogenous such as household composition; economic capacity of involved farmers, skills, and confidence in specific technologies; or exogenous such as lack of extension support, fertilizer-supply, and availability of credit.

A careful identification and exploration of the often manifold and interrelated constraints in complex livelihood settings is an essential first step in identifying relevant opportunities for increasing crop productivity (Fujisaka 1989; Giller et al. 2011).

Currently, constraint identification is often done with desktop modeling studies using crop growth simulation models (e.g. Van Ittersum et al. 2013). Typical products are the yield gap atlas, identifying constraints that are directly derived from model assumptions (e.g., radiation, water, and nutrients) instead of real world analysis. Our review will not include these model derived methods.

Methods for identification of productivity constraints are diverse and range from collecting data on soil properties or crop development, conducting farming system research, experimentation, to tapping traditional knowledge and involving farmers through interviews or group discussions. Many of these methods are mono-disciplinary and do not include socioeconomic complexity of rural households. Others, however, pay more attention to local context and farmer perception. An example to illustrate the importance of considering the local context is the case of using weeds to feed livestock, as is common practice in the Ethiopian Highlands. In these land use systems, grazing areas are very limited. Weeds, therefore, are not considered waste products but seen as an essential forage source for livestock during the cropping season. In addition, the flowers of the weeds are valued as a source of nectar for bees. Weeding, therefore, actually means harvesting cattle fodder, which is even washed to make it more palatable (Fig. 1). Recommending these farmers to use herbicides, to reduce the labor requirements for weeding, therefore meets considerable resistance. Adoption of this technology therefore is not very likely for obvious reasons. In many cases, however, "experts" fail to see this logic and blame the farmers to be traditional or even backward.

In this paper, 16 published papers dealing with systematic identification of crop productivity constraints are reviewed. Context and objectives are specific for each paper. Using a heuristic model, we classify these papers into different methodological clusters. In addition, fitting within these clusters, three prototype methods for constraint identification, are compared within the specific context of low input systems in Tigray, Northern Ethiopia. The heuristic model and comparison are used to discuss in what way the selection of specific methods influences the outcomes of the constraint identification and consequently the selection of opportunities based on it.

\section{Heuristic model and prototype methods}

Important variables to characterize the different methods for the identification of crop productivity constraints are scale level, represented opinion, involvement of stakeholders, responsibility for analysis, used sources of information, and procedural control. Focusing on two variables that are important for the outcomes of constraint identification, i.e., (1) the control over the identification process and (2) the presented opinion/knowledge used to identify the constraints, and considering the two main actors, i.e., the scientist and the farmer, we can create a heuristic model with four categories (see also 


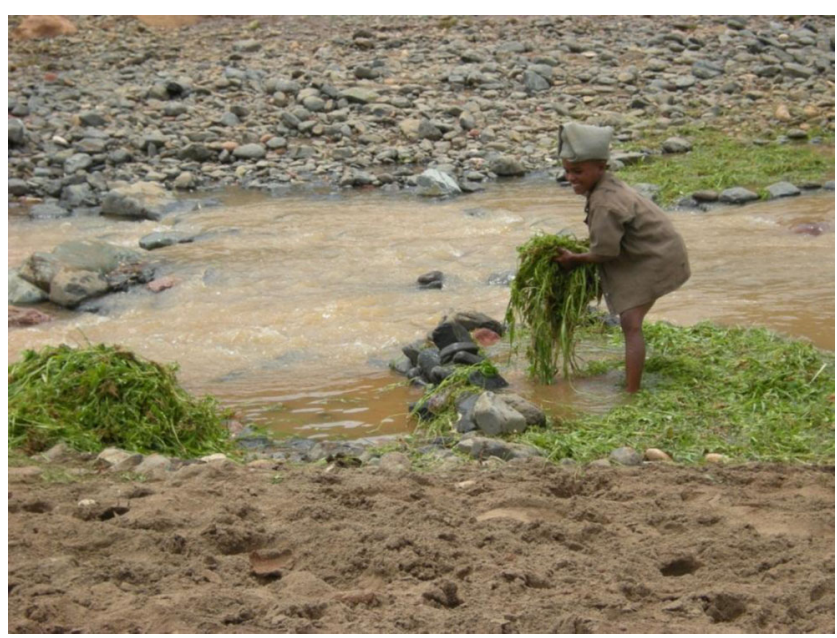

Figure 1 Complexity of farming systems in central Tigray: Young boy washing weeds in a small stream to feed livestock during the cropping season when grazing areas are scarce

Fig. 2): "scientist control-scientist opinion", "scientist controlfarmer opinion", "farmer control-farmer opinion", and "farmer control-scientist opinion".

Between these categories, intergrades are possible but for each category also prototype methods can be found. Relevant within our context are for example:

- Contextual Data Collection (CDC): Scientist controlscientist opinion

- Individual survey (IS): Scientist control-farmer opinion

- Focus group discussion (FGD): Farmer control-farmer opinion

- Consultancy: Farmer control-scientist opinion

With CDC, we refer to data that scientists collect and usually cover a wide range of data from secondary sources: from exact data on soil properties to census data on family composition. Choices are made a priori and reflect the

Figure 2 The reviewed publications with outcomes at different scale levels and prototype methods plotted in a heuristic model (red square; community, green triangle; regional, and purple circle; supranational) reference framework of involved scientists. Scale level is mostly aggregated since data on detailed scales are often not available. Although contextual data collection is an objective method at first sight, it is the scientist who takes decisions on the selection of variables, the thresholdlevels, the sources of data to use and consider, and the final analysis. A bias is easily introduced as a consequence of the orientation of the study, the expertise of the involved scientists, and the availability of data.

Individual surveys (IS) use knowledge and opinions of individual farmers on specific topics through semi-structured or structured interviews. Respondents are direct sources of information, but scientists control the procedure, formulate the questions, and select respondents for interviews. In addition, suggestion from the side of the interviewer and expectations from the side of the respondent may introduce distortion of the collected information. If case data are quantitative, statistical analysis is relatively straightforward. Qualitative outcomes, however, require more efforts. Outcomes can be superficial or in-depth depending on the procedure, type of questions, and the involved respondents. IS can be applied to generate outcomes at different scale levels, ranging from farm to supranational level.

In the case of FGD, the initial focus of the discussion is usually controlled by the researcher. The extend and direction of the following dialogue and discussion vary strongly, depending on the objective of the researcher. However, FGD is usually considered to give space for free group interactions like negotiation and cross-comparisons. These are supposed to result into a shared and balanced opinion. Data are considered to be rich and innovative (Trenkner and Achterberg 1991). Initially, FGDs were applied in the field of marketing, evaluation, and product development (Kidd and Parshall 2000). It now has also become a more popular tool in participatory development processes with four examples in our review.

\section{FARMER CONTROL}

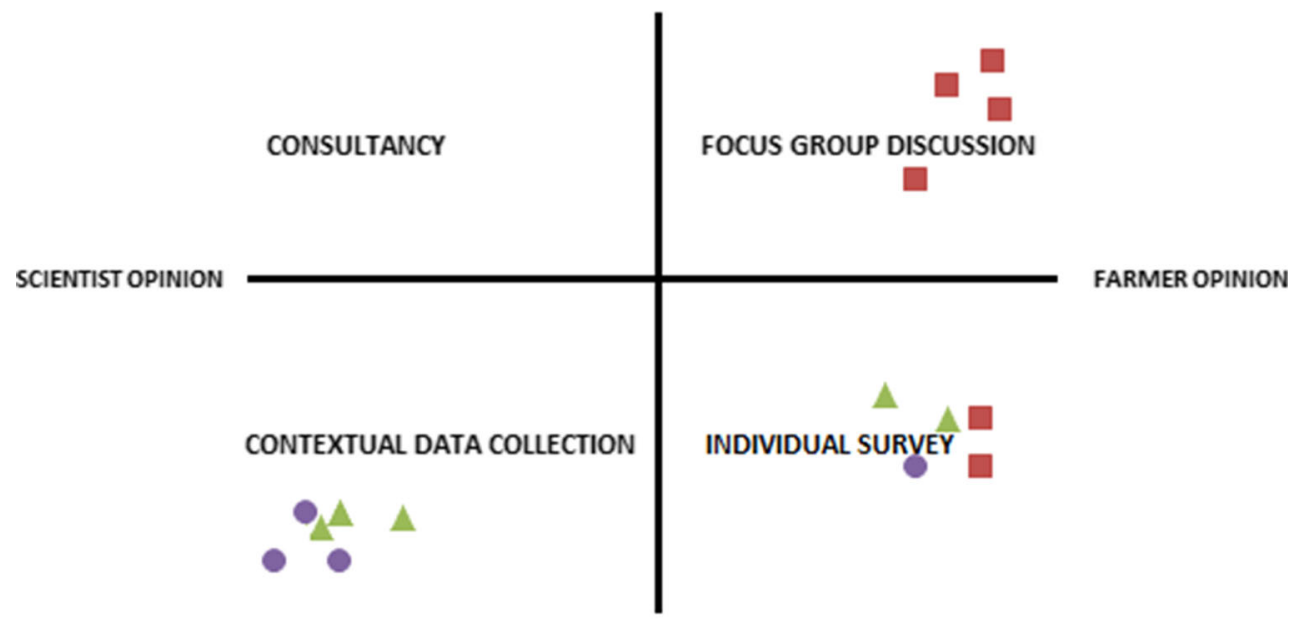

SCIENTIST CONTROL 
The position of the facilitator, that supports the process, is delicate and a possible source of bias. Depending on the objective, participants can be directly involved stakeholders (like farmers) or experts on specific topics. Participants are often preselected for the purpose of stratification. Interpretation of the data is difficult, due to its qualitative nature (Trenkner and Achterberg 1991). In some cases, FGD allows the analysis and interpretation to be partly carried out by the involved participants, like for example in the case of fuzzy cognitive mapping (Kok 2009).

With consultancy, we refer to data collection by experts who are assigned to the task by stakeholders. In the case of "farmer control-scientist opinion", it would be farmers who take the initiative for the constraint identification, but delegate the task to the scientist. The scientist develops the data collection and analysis framework, resulting in a representation of his or her opinion. This type of consultancy is mostly found in more developed settings with high inputs and very specific requests, like for example in large scale commercial farms and plantations.

\section{Different use of methodologies: a review}

\subsection{Presenting outcomes}

Using common literature data-bases (Scopus, Web of Science and Google-scholar), we selected 16 published papers in which crop productivity constraints were identified. To identify and select relevant papers, we used keywords like "crop productivity", "constraint", and "identification". Our focus was on "tropical" and "sub-tropical" environments. The selected papers demonstrated a wide variety in objectives, scale level, methodology, and outcomes.

Fujisaka et al. (1994), for example, discussed the outcomes of diagnostic surveys concerning the identification of research priorities for the rice-wheat cropping system in India and Nepal. Surveys were conducted by multidisciplinary teams of scientists. Opinions of both farmers, derived from individual surveys, and scientists were included. Analysis in a later stage, to indicate research priorities, was done by scientists and partly based on farmer accounts. Their main identified problems were related to crop management, nutrient depletion, and the incidence of pests and diseases.

Kimiti et al. (2007) used participatory discussions in Kenya to ensure the involvement of farmers in the identification of soil fertility constraints. Farmers identified soil erosion as a main factor and perceived poor yields and crop development as an indicator for this decline in fertility. In an additional participatory session, opportunities to deal with such a decline were proposed.
In contrast to such participatory methods, Braimoh et al. (2004) relied on fuzzy logic to determine land suitability for maize production in Northern Ghana based on soil data resulting from 120 sample points. Expert knowledge was used to select variables and the cutoff points required in the applied mathematical procedures. Soil fertility, expressed by effective cation exchange capacity (ECEC), organic carbon, and clay content were identified as a major constraint.

To characterize the applied methods, we used scale-level, methodology, control over the process, represented opinion, identified constraints, and the identified (related) opportunities as main concerns (Table 1).

The scales at which the reviewed methods identified constraints varied from supranational (Waddington et al. 2010; Lançon et al. 2007; Fujisaka et al. 1994; Ajayi 2007), regional (Affholder et al. 2003; Braimoh et al. 2004; Zhang et al. 2004), or to community level (Govindaraj et al. 2010; Kimiti et al. 2007; Odera et al. 2007). The reviewed methods covered a wide range from using science-based expert knowledge (Lançon et al. 2007), evaluation models (Affholder et al. 2003; Braimoh et al. 2004; Zhang et al. 2004), literaturebased data (Drechsel et al. 2001; Ryan 2008), interviews (Uzunlu et al. 1999; Ajayi 2007; Govindaraj et al. 2010), and farmer-based participatory methods (Mowo et al. 2006; Ayenor et al. 2004; Kimiti et al. 2007; Odera et al. 2007).

Control over the process of data collection and interpretation differed considerably between the applied methods. This control ranges from equally distributed between scientist and farmer to more periphery positions. For example, in the case of Affholder et al. (2003), Zhang et al. (2004), Lançon et al. (2007), and Ryan (2008), control is fully by the involved scientific team, whereas in the case of Ayenor et al. (2004), Kimiti et al. (2007), Mowo et al. (2006), and Odera et al. (2007) during major phases, the control over the process is by the involved farmer-stakeholders. Only in the case of Ayenor et al. (2004) also in the final phase, in which the research agenda was determined, farmers were fully involved, for the other cases outcomes mostly served as inputs for next stages in the process.

Methodology also determines the represented opinion, which again ranges between both periphery positions. Scientist-centered opinions can be found with Drechsel et al. (2001), Affholder et al. (2003), and Ryan (2008) whereas Ajayi (2007), Kimiti et al. (2007), and Odera et al. (2007) represent farmer-centered opinions. Identified constraints either had a general scientific character (Mowo et al. 2006; Fujisaka et al. 1994; Affholder et al. 2003) or related to a context-specific grassroots level (Ayenor et al. 2004; Lançon et al. 2007; Kimiti et al. 2007; Govindaraj et al. 2010).

The identified constraints in most cases had an agronomic character and only in the case of Drechsel et al. (2001) and to some extend Bekele (2006) and Ajayi (2007) considered socioeconomic elements. Constraints were generally having 


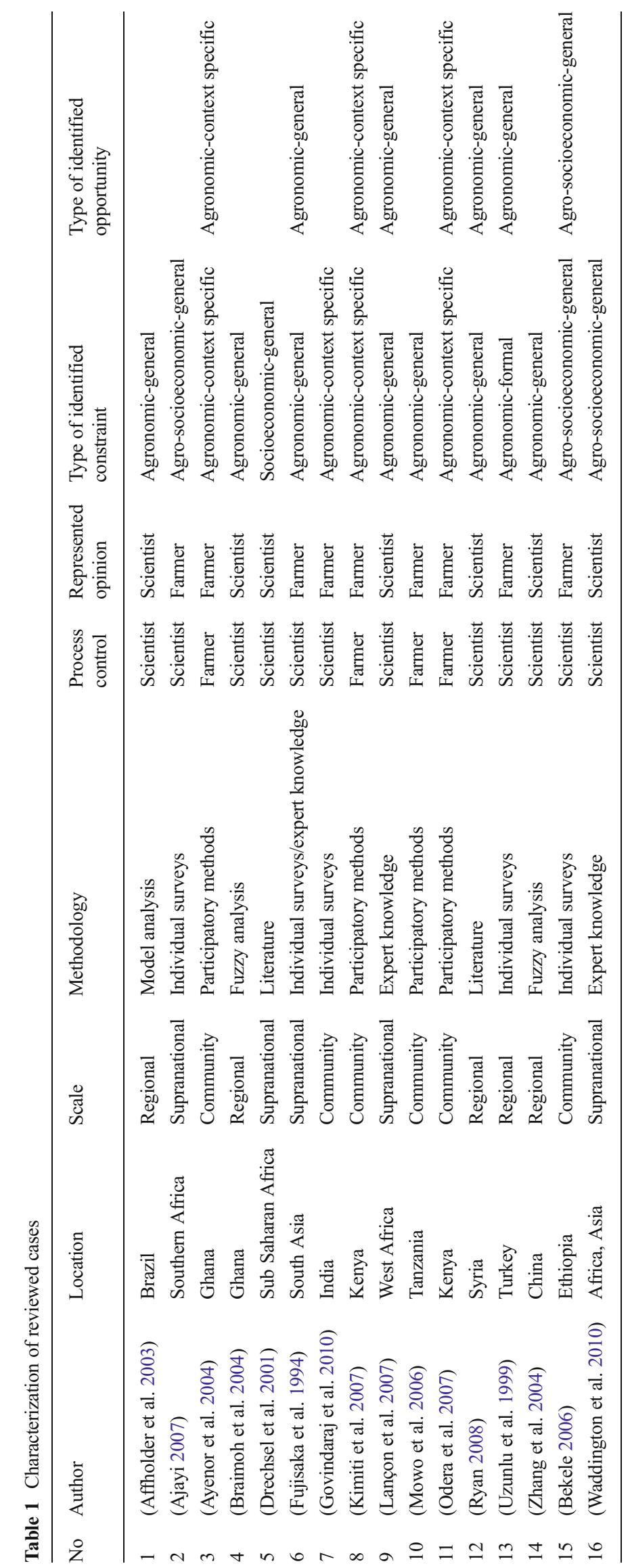


a general character, being only at community level in most cases context specific (Ayenor et al. 2004; Govindaraj et al. 2010).

Some of the reviewed publications also included agronomic opportunities connected to the identified constraints. The character of these constraints was either more general, like for example in Fujisaka et al. (1994), Zhang et al. (2004), and Ryan (2008) or more context specific (Ayenor et al. 2004; Kimiti et al. 2007).

\subsection{Summarizing: using the heuristic model}

The reviewed publications, based on attributed qualitative weight of responsibility for control and opinion and stratified according scale level, can be plotted in the heuristic opinioncontrol model.

For example, Zhang et al. (2004) in China, on a regional scale, uses expert knowledge and fully controls the process, whereas Kimiti et al. (2007) in Kenya uses at community level farmers opinions, and at the same time makes them to some extent responsible for the process. In the model, also the four prototype methods are indicated.

Figure 2 shows that the reviewed cases are belonging to three main clusters: the specific combination of farmer control and scientist opinion was not found among the considered publications. When considering scale-level, the categorization shows that the method which combines farmers opinion and process control, which presumably represents a high degree of participation, generates results that relate to the community level. With scientist-control over the process, also regional and supranational level outcomes are generated. In the category of scientist control and scientist opinion, only higher scale level outcomes are generated. The indication that different methods yielded different types of results motivated our case study in which we compared three different methods within the same area. These methods were selected in such a way that they served as a prototype for categories fitting within our heuristic model.

\section{Comparing different methods for the identification of productivity constraints in Tigray}

\subsection{Background and context}

We aimed to compare three relevant prototype methods for the identification of productivity constraints. These prototype methods, Focus Group Discussion (FGD), Individual Surveys (IS), and Contextual Data Collection (CDC), fitted within the framework of a research project on farmer experimentation. We applied these three methods in four woredas (medium scale administrative units) in the central part of Tigray: Werie-Leke, Hawzen, Ahforom, and Dogua Tembien (Fig. 3). In this study, they are indicated by the names or abbreviations of their respective administrative centers: Edaga Arbi (EA), Hawzen (HW), Inticho (IN), and Hagere Selam (HS).

In each woreda, we selected three or four sub-locations, tabias (small scale administrative units), that provided focus group participants as well as interview respondents. All data were collected from November 2008 till March 2009, except the outcomes of soil analysis which became available in 2012. The outcomes of the different methods were compared and assessed with respect to congruency.

\subsection{Study area description}

In the central part of Tigray, smallholder subsistence farmers using limited external inputs are the main part of the agricultural population. Farm size generally does not exceed 0.75 1.0 ha, and crop productivity is low. Vancampenhout et al. (2006) report for cereals yield-levels of around $700 \mathrm{~kg} / \mathrm{ha}$. This puts the traditional farming system under pressure and given the limited environmental resilience, results in food insecurity, depleted fields, and degraded lands. In the central part of the region, an estimated $40 \%$ of the rural population structurally depends on food-aid, despite the attempts to improve productivity by introducing novel technologies.

In the study area, altitude varies between 1900 and $2600 \mathrm{~m}$. Rainfall depends on altitude and orography and is erratic and highly variable (Nyssen et al. 2005; Haileslassie et al. 2007). Annual precipitation ranges from $522 \mathrm{~mm}$ for HW to $683 \mathrm{~mm}$ for HS (Gebrehiwot and Van der Veen 2013) and is distributed over a short rainy period in March and April and a long rainy period from May till August. Annual mean temperature also depends on altitude and ranges between 15 and $21.5^{\circ} \mathrm{C}$ (Araya et al. 2010).

Most farmers in the study area practice mixed farming. Cattle and small ruminants are grazing depending on the availability of suitable areas. To provide food for the household, different cereals and pulses are grown in a cropping system based on frequent ploughing by oxen.

Wheat, barley, and teff are grown in the long rainy season. Maize, sorghum, and finger millet are planted in March and only will be productive if both rainy seasons overlap.

In some cases, farmers have access to water for irrigation: in HW and HS small hand dug wells and ponds are found, in EA micro-dams with command areas of around 80 ha are present, and in IN diversion structures and motor-pumps are used to extract water from natural streams.

Next to the agroecological differences, the selected woredas vary with respect to intervention history. Between 1975 and 1990, EA was located in a warzone and exposure to development activities was very limited. After 2000, in especially HW and HS, NGOs were implementing multiple development activities, in IN the local Bureau of Agriculture and 
Figure 3 Location of the study area and the involved locations (woredas) in Tigray, Ethiopia

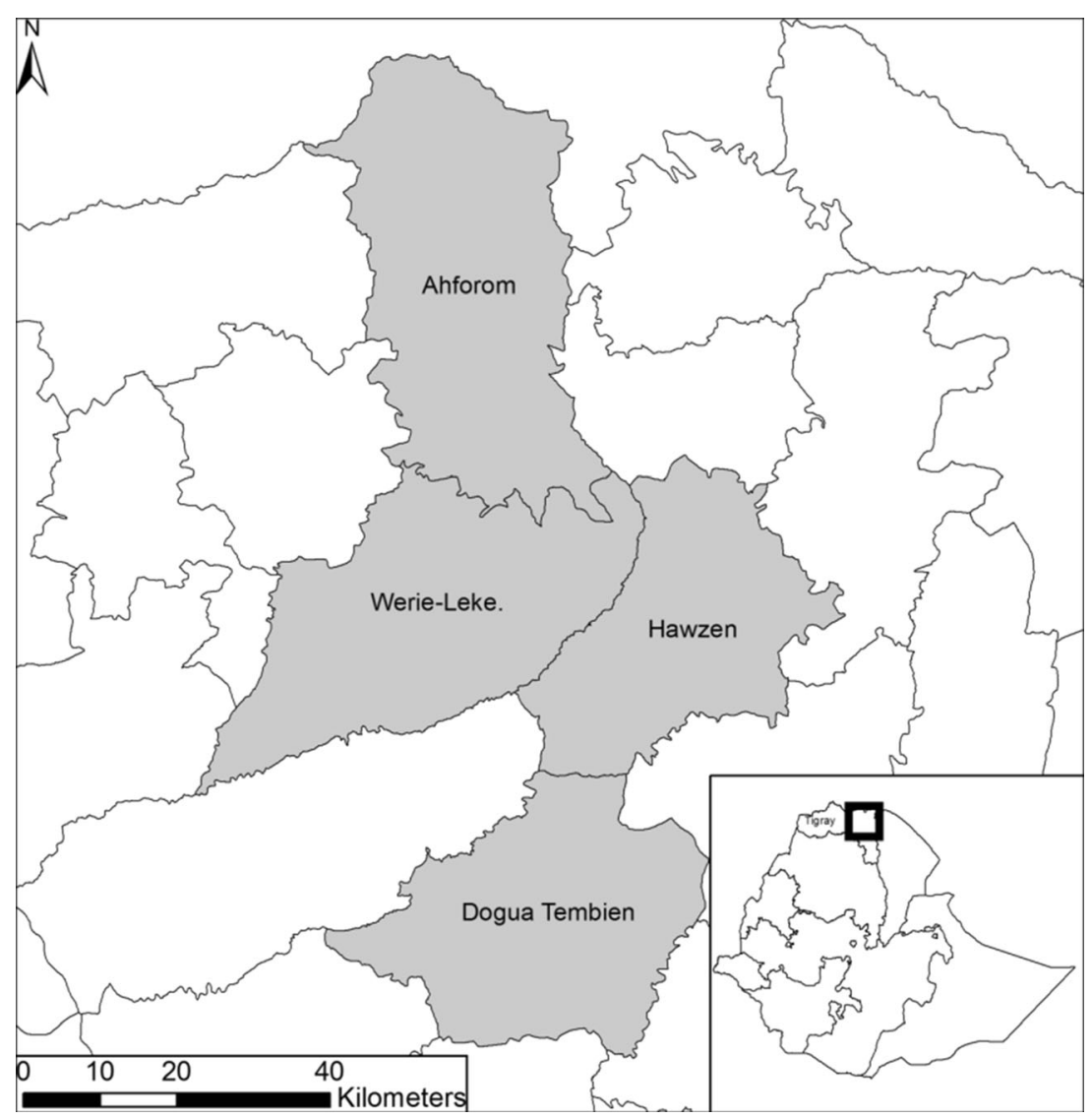

Rural Development (BoARD) has been very actively promoting novel technologies to increase crop productivity.

\subsection{The three prototype methods}

\subsubsection{Focus group discussion}

In each woreda development agents provided names of farmers that were potentially interested to participate in workshops dealing with the issue of crop productivity. Only one out of about 80 approached farmers declined the invitation. We held four workshops, one in each woreda, with about 20 participating farmers in each workshop. Within the workshop, which lasted 1 day, farmers formed four cushet (neighborhood)-based groups, each group identifying and prioritizing their crop productivity issues. In each workshop, we cooperated with the same female moderator.

To allow the proper evaluation within the framework of our research, we took an extreme position with respect to conducting FGD. Process-related interaction in the FGD, as provided by the moderator, was limited to explaining the topic of discussion and reporting its outcomes. We refrained from giving any comments related to crop productivity. We also did not allow BoARD-staff to be present during the discussions to prevent intrusion of external opinions.
Outcomes of the workshops were "rich" pictures. To allow comparisons between the four locations, these rich pictures were translated into spider diagrams using a quantification procedure based on categorization of raised issues according to major concerns (Kraaijvanger 2013). The categories were either constraint or opportunity categories. In this paper, we only consider the constraint categories: (1) conservative management, (2) agronomic factors, (3) location-specific issues, (4) land-related issues, (5) demographic factors, and (6) economic factors.

In our comparison, we use the final outcome of the quantification, relative perceived impact. This index combines the aspect of frequency, by which issues are mentioned and the aspect of weight that is attributed to issues within a specific category (Kraaijvanger 2013).

\subsubsection{Individual survey}

In each woreda, 21 individual surveys on livelihood aspects were conducted with farmers living in the same cushets that provided the FGD-groups. The selection of the respondentfarmers was random, using administrative lists of these cushets. All interviews were held using the same female interpreter.

The individual surveys consisted of open-structured questions which yielded a wide range of data on main social, 
economic, and agronomic issues. In this comparison, we only use data from questions on crop productivity constraints. Responses from farmers were subjected to the same categorization as in the FGD-analysis. To accommodate all raised issues, the category "others" was included.

IS outcomes used in our comparison were calculated as percentage of a specific category in relation to the total of issues raised (Kraaijvanger 2013).

\subsubsection{Contextual data collection}

$\mathrm{CDC}$ on the four woredas covered a set of main agroecological and socioeconomic topics that we considered relevant in relation to agricultural productivity. Census-data like farm-size, household-size, and livestock-number were collected from BoARD-offices at tabia level and averaged to woreda level. Composite soil samples were taken at representative fields in each of the involved tabias and analyzed for main soil properties. Meteorological data were collected at woreda-level. From the resulting dataset (Kraaijvanger 2013), we selected rainfall, $\mathrm{N}$-total, number of livestock, farm size, and household size.

These variables were converted to five constraint variables matching those used in the other applied methods as much as possible: rainfall deficit, rainfall variability, nutrient deficit, land shortage, and relative asset base. To allow comparison, we expressed these variables as percentages of assumed maxima. For this conversion, we used the following procedures:

Rainfall deficit Mean rainfall in the period ranging from February till October was determined for a series of 615 years. In analogy with the concept of agro-climatic zoning (FAO 1978; Araya et al. 2010), we related mean rainfall to potential evapotranspiration to obtain an indication for growth potential. Based on an average evapotranspiration of $6 \mathrm{~mm} /$ day (Doorenbos and Kassam 1979), and a growing period of 100 days, we assumed a total potential evapotranspiration of around $600 \mathrm{~mm}$. The complement of the relation between mean rainfall and assumed evapotranspiration gives the rainfall deficit:

$100-\frac{(\text { Observed mean rainfall } * 100)}{600}=$ rainfall deficit

Rainfall variability Next to the mean, as used in the case of rainfall deficit, also standard deviation, is taken into consideration to obtain an indication for rainfall variability:

$100-\frac{(\text { standard deviation } * 100)}{\text { mean rainfall }}=$ rainfall variability

Nutrient deficit Soil organic matter and especially the nitrogen contained in it are considered essential in assessing soil nutrient status. We therefore related $\mathrm{N}$-total, expressed in milligram per kilogram, to an assumed reference level of $2000 \mathrm{mg} / \mathrm{kg}$ for medium nitrogen availability (Landon 1991) and used its complement as an indication for the nutrient deficit:

$100-\frac{(N-\text { total } * 100)}{2000}=$ nutrient deficit

Lack of assets Livestock is often considered a main indicator for wealth in smallholder mixed farming systems (Zingore et al. 2007). To estimate the relative resource basis, we calculated the number of tropical livestock units (TLU) according to Abegaz et al. (2007). This was referenced to an assumed local maximum of $6.0 \mathrm{TLU}$, which stands for the number of livestock of the "richest" farmers in the study area. The obtained relative resource basis was converted to an indicator relating to the lack of assets by taking its complement:

$100-\frac{(\text { TLU } * 100)}{6.0}=$ lack of assets

Land shortage For smallholder subsistence farmers scarcity of land basically refers to a lacking capacity to support household needs. In analogy with Hadgu (2008), we therefore calculated an indicator for land shortage based on household, farm size, and an estimated caloric production and requirement. We assumed, based on an average cereal-productivity of $1200 \mathrm{~kg} / \mathrm{ha}$ with an average energy of $15 \mathrm{MJ} / \mathrm{kg}$ (Norman et al. 1995), a caloric produce of 1 ha of land of 18 GJ. Additionally, a daily energy requirement of $8 \mathrm{MJ}$ per household member was calculated based on Werner et al. (2001). Based on the size of the farm and the number of household members, the ratio between produced and required food is calculated and converted to a land shortage indicator by taking its complement:

$100-\frac{(\text { acreage } * 18000 * 100)}{(\text { householdsize } * 8 * 365)}=$ land shortage

\subsection{Assessment of congruency}

Congruency of the used methods was assessed by paringrelated categories, as shown in Table 2, for each combination of methods (FGD-IS, FGD-CDC, and IS-CDC). Ranks for the outcomes of the methods were attributed according to the following procedure: 1 ; lowest, 2 ; in between, and 3 ; highest. Attributed ordinal rankings for these categories were tested for correlation using Spearman- $\rho$.

The same procedure was applied to determine the correlation between the four sites with respect to specific categories for each of the methods. 
Table 2 Overview of constraint categories as covered by Focus Group Discussion, Individual Surveys, and Contextual Data Collection

\begin{tabular}{lll}
\hline Focus group discussion & Individual survey & Contextual data collection \\
\hline Conservative management & Conservative management & \\
Agronomic factors & Agronomic factors & \\
Economic factors & Economic factors & Lack of assets \\
Demographic factors & Demographic factors & Land shortage \\
Land-related issues & Land-related issues & Nutrient deficit \\
Location-specific issues & Location-specific issues & Rainfall variability \\
& Other & \\
& & Rainfall deficit \\
\hline
\end{tabular}

A high correlation between two methods implies their congruency, for example when for both methods a specific category scores in a specific woreda the same rank. High correlation between the woredas, under the assumption them to be different, suggests outcomes to be predetermined by methodology. This is the case when for example a specific constraint category in all four woredas for a specific method scores the same rank. Low correlation between the woredas due to diverse identified constraints, at the other hand might reflect, again under the assumption of contextual diversity, a more contextsensitive methodology. An example of this is when a constraint category scores in the four woredas all possible ranks (1, 2, and 3) for a specific method.

\subsection{Outcomes of applied methods}

For each location, the outcomes of the methods are presented as percentages in radial diagrams to allow comparison (Table 3). For EA, location-specific issues were most frequently mentioned as productivity constraint in FGD. In contrast, economic and demographic factors were most frequently mentioned in IS, and nutrient deficiency became apparent in the CDC. For HW, location-specific issues were mentioned as a main productivity constraint. IS and CDC pointed to economic factors and nutrient deficit respectively, as main constraints for productivity.

For both IN and HS, demographic factors were dominant in FGD. However, demographic factors and land shortage did not came out as relevant issues using IS and CDC. Using IS in both IN and HS showed that agronomic factors were mentioned as a main factor. Lack of assets was identified as a main constraint using CDC. Similarities in identified constraints for the involved locations can especially be observed when comparing diagrams resulting from the use of IS and CDC.

\subsection{Comparability of outcomes}

Spearman- $\rho$ correlations between the outcomes of the compared methods were only low (Table 4). Correlations between the methods were positive, except for the combination of FGD-IS (constraints), which showed a negative correlation.
Congruency between the compared methods therefore isn't very likely.

A relatively high Spearman- $\rho$ correlation $(R>0.70)$ was demonstrated between the four locations with respect to the outcomes when using IS and CDC. Applying FGD to identify constraints resulted in a relatively low correlation $(\mathrm{R}<0.50)$ between the woredas.

\section{Discussion}

\subsection{Review of selected papers}

The review of 16 papers yielded a wide variation in methods and procedures which are used for the identification of constraints in relation to crop productivity. This variation is manifest in for example the use of specific data sources and different responsibilities for procedures and interpretation. Uniformity in methodology at this end is absent. Scale level and objectives to a large extent determine the selection of a specific methodology.

In most cases, quite general constraints are identified. This contrasts with the multiple, context- and interdependent constraints that are usually considered relevant for successful development-oriented interventions. In our review, only community-level methods yielded the identification of context-relevant constraints. This is not surprising, but at the same time questions the energy invested in the identification of often obvious and general constraints. Exemplary in this are the constraints identified in a supranational yield gap analysis (Waddington et al. 2010) forwarding an almost equal responsibility for each of the identified constraints.

When considering the reviewed participatory methods, we observe that these are quite diverse with respect to the responsibilities delegated to the farmers. For being participatory, ideally some degree of control for the involved farmers is compulsory (Pretty 1995), researchers however often seem afraid to delegate this control. Govindaraj et al. (2010), for example, claimed the application of participatory techniques but actually the influence of farmers was restricted to providing information, which fits more with individual surveys. 
Table 3 Relative score's (as \% of an assumed maximum) for different constraint categories as identified by Focus Group Discussion, Individual Surveys, and Contextual Data Collection for four different locations in central Tigray

\begin{tabular}{|c|c|c|c|}
\hline & Focus Group Discussion & Individual Surveys & Contextual Data Collection \\
\hline D̂. & $\begin{array}{c}\begin{array}{c}\text { demographic } \\
\text { factors }\end{array} \\
\text { economic factors } \\
\text { location specific } \\
\text { issues }\end{array}$ & $\begin{array}{c}\text { location specific } \\
\text { issues } \\
\text { femographic } \\
\text { factors }\end{array}$ & of assets \\
\hline 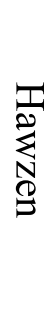 & $\begin{array}{c}\text { demographic } \\
\text { factors }\end{array}$ & $\begin{array}{c}\text { conservative } \\
\text { demographic } \\
\text { factors }\end{array}$ & land shortage \\
\hline 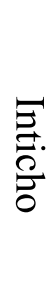 & $\begin{array}{c}\text { conservative } \\
\text { management } \\
\text { economic } \\
\text { factors } \\
\text { factors } \\
\text { location } \\
\text { specific issues } \\
\text { issues }\end{array}$ & $\begin{array}{c}\text { Conservative } \\
\text { management } \\
\text { demographic } \\
\text { factors }\end{array}$ & $\begin{array}{l}\text { lack of assets } \\
\text { land shortage }\end{array}$ \\
\hline 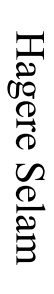 & $\begin{array}{c}\text { demographic } \\
\text { factors }\end{array}$ & $\begin{array}{c}\text { Conservative } \\
\text { demographic } \\
\text { factors }\end{array}$ & land shortage \\
\hline
\end{tabular}

\subsection{Comparison of different methods within the} same case study

The three methods we compared yielded considerably different types and priorities of crop productivity constraints. This implies that they are not 1-1 exchangeable.

FGD generated a contextually differentiated multi-focused set of constraints. Only location-specific issues can be considered a common denominator for all woredas. This seems consistent with the character of FGD in which group interaction and negotiation are likely to address complexity and context. The importance of group interactions within FGD was also found by Asfaw et al. (2012) who concluded that group outcomes were more diverse and likely to be more relevant as compared to data from individual surveys. 
Table 4 Spearman- $\rho$ correlations between different combinations of methods and between different locations

\begin{tabular}{lll}
\hline Concern & Evaluated method(s) & Correlation-coefficient \\
\hline Congruency & Focus group discussion, Contextual data collection & 0.255 \\
Congruency & Focus group discussion, Individual surveys & -0.312 \\
Congruency & Individual surveys, Contextual data collection & 0.125 \\
Outcome variability & Focus group discussion & $0.454^{*}$ \\
Outcome variability & Individual surveys & $0.711^{*}$ \\
Outcome variability & Contextual data collection & $0.875^{*}$ \\
\hline
\end{tabular}

*Significant at $p=0.05$ level

The IS-outcomes tended to provide a single-focus picture which primarily relates to short-term concerns of individual farmers. Agronomic and economic factors seem specifically prioritized and mentioning these issues might be directed by expectations in relation to obtaining support, for example in the form of credit or supply of farm-inputs. Critical reflection is often lacking, resulting in somewhat superficial outcomes.

The quality of CDC as a method depends heavily on quality of the used data and the use of appropriate thresholds. In our case, we rate the reliability of the rainfall data as doubtful; this might have resulted in a too optimistic interpretation.

The outcomes for CDC are very similar for the different locations, despite their biophysical variability. They indicate as main constraints that farmers lack assets and soils are nutrient deficient. This might be a consequence of the preselection of variables and threshold levels. Including more detailed variables and data seems a logical option, but then tends to convert CDC into a farming system analysis.

Correlation between the outcomes of different woredas was high in the case of IS and CDC. For FGD is correlation was much lower. Based on the assumption of different agroecological and socioeconomic contexts of the involved woredas (Kraaijvanger 2013), this suggests differences in context sensitivity for the different applied methods, with FGD seeming the most context sensitive method.

\subsection{Epistemological foundations}

The aspects of process control and represented opinion, the foundations of our heuristic model, allowed us to differentiate between the reviewed cases. This resulted in three main categories.

Control over the identification process is extremely important since many pre-analytical choices are involved. Clear examples are the selection of variables and data sources, and attributed responsibilities for interpretation. Such decisions at the same time will determine the content and reliability of the generated outcomes (Röling et al. 2004). Only raised questions will be answered and only selected variables be considered.
With respect to represented opinion, it is important to realize that scientists and farmers use different sources of knowledge, which is generated with different procedures and in different contexts (Dea and Scoones 2003; Hoffmann et al. 2007; Maat 2011). Different represented opinions therefore likely will result in different outcomes.

Both process control and represented opinion are clearly essential elements of methods for constraint identification that have a manifest impact on generated outcomes and their applicability. Researchers, therefore, should explicitly consider these methodological aspects and indicate who is in control of the research and whose opinions are represented. Being conscious of their position in the opinion-control framework consequently will lead to more concern about the selection and epistemology of applied methodologies.

\subsection{From identification of constraints to forwarding opportunities}

Based on constraint identification in many cases opportunities will be forwarded to support intervention work. In development processes not only a just academic identification of constraints, but especially the way how to deal with them in practical setting counts.

To achieve adoption of forwarded opportunities by farmers requires an understanding of their preferences and motivations (Bekele 2006; Ajayi 2007; Knowler and Bradshaw 2007). Forwarded technologies should fit in the existing livelihood systems and be supportive to the overall perceived sustainability of farming systems (Sumberg et al. 2003; Sumberg 2005; Bekele 2006).

Successful novel technologies should not only be technological sound but in also match with the complex sociocultural setting in which smallholder farmers operate (Sturdy et al. 2008; Hailu 2009). New technologies in addition need to match with available competence and capacity to allow smooth integration into existing livelihood systems. Such integration likely will secure sustainable development (Altieri et al. 2012).

In arriving at such opportunities, it again matters who selects them from which basket full of options in the sense 
of Tittonell and Giller (2013). Considering this, the opinioncontrol framework also seems relevant with respect to processes aiming at the identification of opportunities.

\section{Conclusions}

The literature review demonstrated for the different applied methods that farmers and scientists hold different positions with respect to process control and represented opinion. Comparison of associated prototype methods indicated that these were not congruent and as such not exchangeable. Major differences between the methods, with respect to identified constraints, were found.

These differences can be related to methodological characteristics of the applied methods.

Explicit and purposive labeling of methods for constraint identification with respect to process control and represented opinion consequently might lead to a more concerned selection, design, and application of these methods.

\section{References}

Abegaz A, van Keulen H, Oosting SJ (2007) Feed resources, livestock production and soil carbon dynamics in Teghane, Northern Highlands of Ethiopia. Agr Syst 94(2):391-404. doi:10.1016/j. agsy.2006.11.001

Affholder F, Scopel E, Neto JM, Capillon A (2003) Diagnosis of the productivity gap using a crop model. Methodology and case study of small-scale maize production in central Brazil. Agronomie 23(4): 305-325

Ajayi OC (2007) User acceptability of sustainable soil fertility technologies: Lessons from farmers' knowledge, attitude and practice in Southern Africa. J Sustain Agric 30(3):21-40. doi:10.1300/ J064v30n03 04

Altieri MA, Funes-Monzote FR, Petersen P (2012) Agroecologically efficient agricultural systems for smallholder farmers: Contributions to food sovereignty. Agron Sustain Dev 32(1):1-13. doi:10.1007/s13593-011-0065-6

Araya A, Keesstra SD, Stroosnijder L (2010) A new agro-climatic classification for crop suitability zoning in northern semi-arid Ethiopia. Agr Forest Meteorol 150(7-8):1057-1064. doi:10.1016/j.agrformet. 2010.04.003

Asfaw A, Almekinders CJM, Blair MW, Struik PC (2012) Participatory approach in common bean (Phaseolus vulgaris L.) breeding for drought tolerance for southern Ethiopia. Plant Breed 131(1):125134. doi:10.1111/j.1439-0523.2011.01921.x

Ayenor GK, Röling NG, Padi B, Van Huis A, Obeng-Ofori D, Atengdem PB (2004) Converging farmers' and scientists' perspectives on researchable constraints on organic cocoa production in Ghana: Results of a diagnostic study. NJAS-Wagen J Life Sci 52(3-4): 261-284

Bekele W (2006) Analysis of farmers' preferences for development intervention programs: a case study of subsistence farmers from East Ethiopian Highlands. Afr Dev Rev 18(2): $183-204$
Braimoh AK, Vlek PLG, Stein A (2004) Land evaluation for maize based on fuzzy set and interpolation. 33,(2), 226-238. DOI: 10.1007/ s00267-003-0171-6

Chambers R, Jiggins J (1987) Agricultural research for resource-poor farmers part I: Transfer-of-technology and farming systems research. Agric Adm Ext 27(1):35-52

Dea D, Scoones I (2003) Networks of knowledge: How farmers and scientists understand soils and their fertility. A case study from Ethiopia. Oxf Dev Stud 31(4):461-478. doi:10. 1080/1360081032000146636

Denning G, Kabambe P, Sanchez P, Malik A, Flor R, Harawa R, Nkhoma P, Zamba C, Banda C, Magombo C, Keating M, Wangila J, Sachs J (2009). input subsidies to improve smallholder maize productivity in malawi: toward an african green revolution. PloS Biol 7(1). DOI: 10.1371/journal.pbio.1000023

Dethier JJ, Effenberger A (2012) Agriculture and development: a brief review of the literature. Econ Syst 36(2):175-205. doi:10.1016/j. ecosys.2011.09.003

Doorenbos J, Kassam AH (1979) Yield response to water. FAO, Rome

Drechsel P, Gyiele L, Kunze D, Cofie O (2001) Population density, soil nutrient depletion, and economic growth in sub-saharan Africa. Ecol Econ 38(2):251-258. doi:10.1016/s0921-8009(01)00167-7

FAO (1978) Report on the agro-ecological zones project. Methodology and results for Africa. Food and Agricultural Organization, Rome

Fujisaka S (1989) The need to build upon farmer practice and knowledge: Reminders from selected upland conservation projects and policies. Agrofor Syst 9(2):141-153. doi:10.1007/bf00168259

Fujisaka S, Harrington L, Hobbs P (1994) Rice-wheat in South Asia: Systems and long-term priorities established through diagnostic research. Agr Syst 46(2):169-187. doi:10.1016/0308-521x(94) 90096-X

Gebrehiwot T, Van der Veen A (2013) Assessing the evidence of climate variability in the northern part of Ethiopia. J Dev Agric Econ 5(3): 104-119. doi:10.5897/JDAE12.056

Giller KE, Tittonell P, Rufino MC, van Wijk MT, Zingore S, Mapfumo P, Adjei-Nsiah S, Herrero M, Chikowo R, Corbeels M, Rowe EC, Baijukya F, Mwijage A, Smith J, Yeboah E, van der Burg WJ, Sanogo OM, Misiko M, de Ridder N, Karanja S, Kaizzi C, K'Ungu J, Mwale M, Nwaga D, Pacini C, Vanlauwe B (2011) Communicating complexity: Integrated assessment of trade-offs concerning soil fertility management within African farming systems to support innovation and development. Agr Syst 104(2):191203. doi:10.1016/j.agsy.2010.07.002

Govindaraj G, Kumari J, Mishra A, Bharti VS (2010) Problem identification and prioritisation of research options: the PRA and AHP approach. J Rural Dev 29(4):449-455

Hadgu KM (2008) Temporal and spatial changes in land use patterns and biodiversity in relation to farm productivity at multiple scales in Tigray, Ethiopia. Wageningen University, Wageningen

Haileslassie A, Priess JA, Veldkamp E, Lesschen JP (2007) Nutrient flows and balances at the field and farm scale: exploring effects of land-use strategies and access to resources. Agr Syst 94(2):459-470. doi:10.1016/j.agsy.2006.11.013

Hailu B (2009) The impact of agricultural policies on smallholder innovation capacities Communication and innovation studies. Wageningen University, Wageningen, p 155

Hengsdijk H, Meijerink GW, Mosugu ME (2005) Modeling the effect of three soil and water conservation practices in Tigray, Ethiopia. Agric Ecosyst Environ 105(1-2):29-40. doi:10.1016/j.agee.2004.06.002

Hoffmann V, Probst K, Christinck A (2007) Farmers and researchers: How can collaborative advantages be created in participatory research and technology development? Agric Hum Values 24(3):355368. doi:10.1007/s10460-007-9072-2

Kidd PS, Parshall MB (2000) Getting the focus and the group: Enhancing analytical rigor in focus group research. Qual Health Res 10(3):293308 
Kimiti J., A. Esilaba, B. Vanlauwe, A. Bationo, (2007) Participatory diagnosis in the eastern drylands of kenya: are farmers aware of their soil fertility status?advances in integrated soil fertility management in sub-saharan africa: challenges and opportunities. springer, pp. 961-968

Knowler D, Bradshaw B (2007) Farmers' adoption of conservation agriculture: a review and synthesis of recent research. Food Policy 32(1):25-48. doi:10.1016/j.foodpol.2006.01.003

Kok K (2009) The potential of fuzzy cognitive maps for semi-quantitative scenario development, with an example from Brazil. Glob Environ Chang 19(1):122-133

Kolavalli S, Kerr J (2002) Scaling up participatory watershed development in India. Dev Chang 33(2):213-235

Kraaijvanger R., 2013. PE\&RC-08060-Working document I: Phase (2008-2009), available under http://edepot.wur.nl/259130.

Lançon J, Wery J, Rapidel B, Angokaye M, Gérardeaux E, Gaborel C, Ballo D, Fadegnon B (2007) An improved methodology for integrated crop management systems. Agron Sustain Dev 27(2):101110. doi:10.1051/agro:2006037

Landon J.R. (1991) Booker tropical soil manual : a handbook for soil survey and agricultural land evaluation in the tropics and subtropics. Longman [etc.], Harlow [etc.].

Longhurst R, Lipton M (1989). The role of agricultural research and secondary food crops in reducing seasonal food security. Seasonal variability in Third World agriculture, 285-297

Maat H (2011) The history and future of agricultural experiments. NJASWagen J Life Sci 57(3-4):187-195. doi:10.1016/j.njas.2010.11.001

Mowo JG, Janssen BH, Oenema O, German LA, Mrema JP, Shemdoe RS (2006) Soil fertility evaluation and management by smallholder farmer communities in northern Tanzania. Agric Ecosyst Environ 116(1-2):47-59. doi:10.1016/j.agee.2006.03.021

Norman MJT, Pearson CJ, Searle PGE (1995) Tropical food crops in their environment. Cambridge University, Cambridge

Nyssen J, Poesen J, Moeyersons J, Deckers J, Haile M, Lang A (2004) Human impact on the environment in the Ethiopian and Eritrean highlands - a state of the art. Earth Sci Rev 64(3-4):273-320. doi: 10.1016/S0012-8252(03)00078-3

Nyssen J, Vandenreyken H, Poesen J, Moeyersons J, Deckers J, Haile M, Salles C, Govers G (2005) Rainfall erosivity and variability in the Northern Ethiopian Highlands. J Hydrol 311(1-4):172-187

Odera M., S. Kimani, A. Esilaba, J. Kaiyare, E. Mwangi, E. Gachanja, (2007). Factors determining integrated soil fertility management in central Kenya highlands: participatory learning and action (plar) model analysisadvances in integrated soil fertility management in sub-saharan africa: challenges and opportunities. Springer, pp. 1019-1026

Pretty JN (1995) Participatory learning for sustainable agriculture. World Dev 23(8): 1247-1263

Röling NG, Hounkonnou D, Offel SK, Tossou R, Van Huis A (2004) Linking science and farmers' innovative capacity: diagnostic studies from Ghana and Benin. NJAS-Wagen J Life Sci 52(3-4):211-235
Ryan J (2008) Crop nutrients for sustainable agricultural production in the drought-stressed mediterranean region. J Agr Sci Tech 10(4):295306

Sturdy JD, Jewitt GPW, Lorentz SA (2008) Building an understanding of water use innovation adoption processes through farmer-driven experimentation. Phys Chem Earth 33(8-13):859-872. doi:10. 1016/j.pce.2008.06.022

Sumberg J (2005) Constraints to the adoption of agricultural innovations: is it time for a re-think? Outlook Agric 34(1):7-10

Sumberg J, Okali C, Reece D (2003) Agricultural research in the face of diversity, local knowledge and the participation imperative: Theoretical considerations. Agr Syst 76(2):739-753. doi:10.1016/ s0308-521x(02)00153-1

Tittonell P, Giller KE (2013) When yield gaps are poverty traps: the paradigm of ecological intensification in african smallholder agriculture. Field Crop Res 143:76-90. doi:10.1016/j.fcr.2012.10.007

Trenkner LL, Achterberg CL (1991) Use of focus groups in evaluating nutrition education materials. J Am Diet Assoc 91(12):1577-1581

Uzunlu V, Bayaner A, Beniwal Icarda SPS (1999) Problem identification and priority setting in agricultural research: the case of the eastern margin of central Anatolia. Turk J Agric For 23(6):679-686

Van Ittersum MK, Cassman KG, Grassini P, Wolf J, Tittonell P, HochmanZ (2013) Yield gap analysis with local to global relevance-A review. 143, 4-17. DOI: 10.1016/j.fcr.2012.09.009.

Vancampenhout K, Nyssen J, Gebremichael D, Deckers J, Poesen J, Haile M, Moeyersons J (2006) Stone bunds for soil conservation in the northern Ethiopian highlands: Impacts on soil fertility and crop yield. Soil Tillage Res 90(1-2):1-15

Veldkamp A, Verburg PH, Kok K, De Koning GHJ, Priess J, Bergsma AR (2001) The need for scale sensitive approaches in spatially explicit land use change modeling. Environ Model Assess 6(2): 111-121. doi:10.1023/a:1011572301150

Waddington SR, Li X, Dixon J, Hyman G, de Vicente MC (2010) Getting the focus right: Production constraints for six major food crops in asian and african farming systems. Food Secur 2(1):27-48. doi:10. 1007/s12571-010-0053-8

Werner D, Thumann C, Maxwell J, Pearson A (2001) Where there is no doctor (for Ethiopia), a village health care handbook. Shama Books, Addis Abeba

Zhang B, Zhang Y, Chen D, White RE, Li Y (2004) A quantitative evaluation system of soil productivity for intensive agriculture in China. Geoderma 123(3-4):319-331. doi:10.1016/j.geoderma. 2004.02.015

Zingore S, Murwira HK, Delve RJ, Giller KE (2007) Influence of nutrient management strategies on variability of soil fertility, crop yields and nutrient balances on smallholder farms in Zimbabwe. Agric Ecosyst Environ 119(1-2):112-126. doi: 10.1016/j.agee.2006.06.019 